\title{
MODERN MANAGEMENT CHALLENGES OF FLOATING HOUSING DEVELOPMENT
}

\author{
Emilia Miszewska-Urbańska, M.Sc. \\ Faculty of Civil Engineering and Environment \\ Gdańsk University of Technology \\ e-mail: emiurban@pg.gda.pl
}

\begin{abstract}
The aim of the article is to identify factors that determine the development and management models of floating housing development in the analyzed countries. The author indicates factors determining the possibility of settling on bodies of water in Poland, and restrictions connected with this type of development, as well as the need for specialized persons and companies ready to meet the challenges of the modern management of hydro-technical facilities, including floating housing development.

In Western Europe, living on water is gaining in popularity. People have begun to dwell on water because of rising land prices, congestion in cities and work related to the use of rivers for the transport of goods.

The popularity of housing on water in the Netherlands results from environmental conditions. About $60 \%$ of the Netherlands is below the sea level. For hundreds of years, the population of the Netherlands has been battling with the elements, while being exposed to continuously rising sea levels, which has been a consequence of the greenhouse effect. Environmental changes have caused a change in government policy, which began to support construction activity on water, adapted regulations and changed office holders.

In North America, especially in the United States, the identification of residents with their neighborhoods of houses on water is so high that it has resulted in the formation of communities uniting owners of residential watercrafts, who have succeeded in homes on water becoming recognized as real estate and, consequently, now have the same rights as residents of houses on land.

In Poland, housing estates on water are slowly gaining popularity but no factors determining the development of this type of settlement have been established. An analysis of the situation in Poland reveals many factors limiting the functional use of houses on water and a lack of specialists in the management of hydro-technical facilities. Therefore, on the basis of examples of countries in Western Europe and North America given in this article, the author tries to define the responsibilities of managers and an appropriate management model for housing estates on water in Poland, as well as indicate problems with the development of housing on water and their possible solutions.
\end{abstract}

Key words: housing on water, management, waterside areas.

JEL Classification: R20, Z19.

Citation: Miszewska-Urbańska E., 2016, Modern Management Challenges of Floating Housing Development, Real Estate Management and Valuation, Vol. 24, No. 1, pp. 31-40.

DOI: 10.1515/remav-2016-0003

\section{Introduction}

In the second half of the twentieth century, a process closely linked to the revitalization of the riverside was initiated. It has been noticed that the cities have begun planning construction so as to face the river (PANCEWICZ 2004). In recent years the "renaissance of quays" took on a global dimension, changing the way of thinking about water and its proximity (KOCHANOWSKI 1998; BAŃKOWSKA 2000; LORENS 2004). 
Currently, the importance of quays and riverside areas is being discovered around the world, which in new realities and economic, political and business conditions, due to transformation, can bring economic benefits by contributing to the development of the city and its competitiveness. (MUSZYŃSKA-JELESZYŃSKA 2012). Changes in waterfront areas and the local and global impact they have on urban areas is the subject of numerous publications, i.e. HOYLE (2000), HARMS (1997).

Post-industrial areas, especially old ports, are particularly noteworthy. As a result of economic changes, they have discontinued production, which was directly or indirectly related to transhipment ports, and have instead focused on residential and service functions. An important element of this diversion is not only the change of the waterfront and adjacent areas, but also the use of water as a new direction of urban development (GERIGK 2013). Germany is one of the countries in Western Europe where the changes in the function of post-industrial areas into residential and service functions are visible. These have led to the creation of not just individual houses on water, but also whole estates, equipped with the same utilities and facilities available to apartments located on land.

More and more often, the issue of the revitalization of urban areas bordering waterways, i.e. channels or rivers, is raised in Poland. Apartments with parking spaces at the marina, located within a short distance from the apartment, are becoming increasingly popular. The restructuring of the shipbuilding market in Poland, once thriving and expanding, has been drastically reduced in the current economic situation. This has resulted in large vacant areas being created in place of the unprofitable shipyards. The closure of shipyards has resulted in the creation of additional potential for the development of floating housing, along with challenges connected with the modern-day management of residential areas on water.

\section{Global trends of settlement on water}

The culture of constructing residential buildings on water has a long tradition in Europe, as well as Asia and North America. At each of these latitudes, construction activity on water arises for different reasons.

The Netherlands is a leader in housing on water in Europe. There are two main justifications of such interest in floating residential units. Firstly, the Netherlands belongs to the group of the most densely populated countries. Secondly, there is the fact that about $60 \%$ of its surface is below the sea level. For hundreds of years, the population of the Netherlands has been battling with the elements, while being exposed to continuously rising sea levels, which are the result of the greenhouse effect. Originally, the process was aimed at draining more areas and obtaining building land from the sea, but environmental, technological and economic changes resulted in a change of government policy. The country began to support construction activities on water, building housing estate vessels (residential barges or buildings constructed on floating platforms); it adapted laws and put new office holders into power. One of the most popular and prestigious floating estates in the Netherlands is Waterbuurt. It is located in Amsterdam and is a part of the district of IJburg; the residential settlement includes 75 (or, according to the Financial Times, as many as 93) floating homes moored to jetties as shown in Photograph 1.

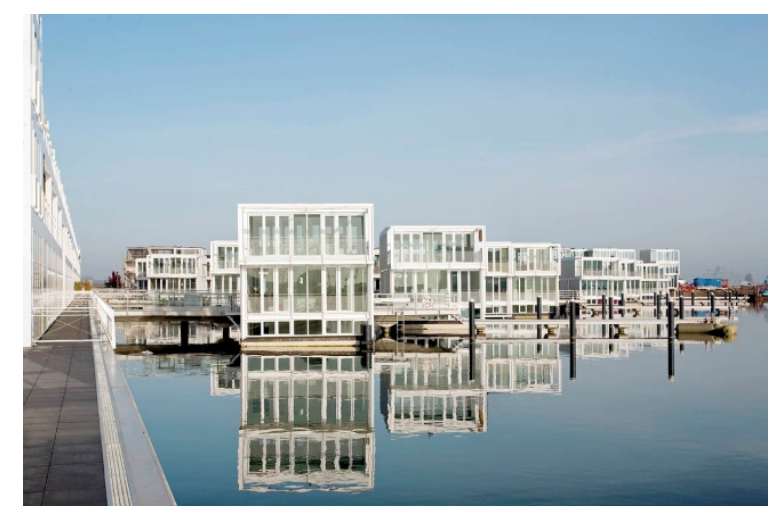

Phot. 1. A settlement of floating homes in IJburg, Amsterdam. Source: www.amusingplanet.com.

In the UK, taking up residence on water was a result of the industrial revolution. Long narrow boats called narrowboats, initially moved by draught horses, transported huge quantities of raw materials and fuels for industry. Over time, the distances became longer and longer and the work 
increasingly harder, as a result of which entire families of "rowers" moved from land to water, while horses were replaced by steam engines, and later by internal combustion engines.

In the cities, most narrowboats are moored along quays of canals and rivers which can be seen in Figure 1. The main determinants of this form of settlement on water bodies in England are sailing conditions, and the widths of the rivers and canals. In the towns and villages, one can find small and medium-sized harbors where owners of these units are gathered.

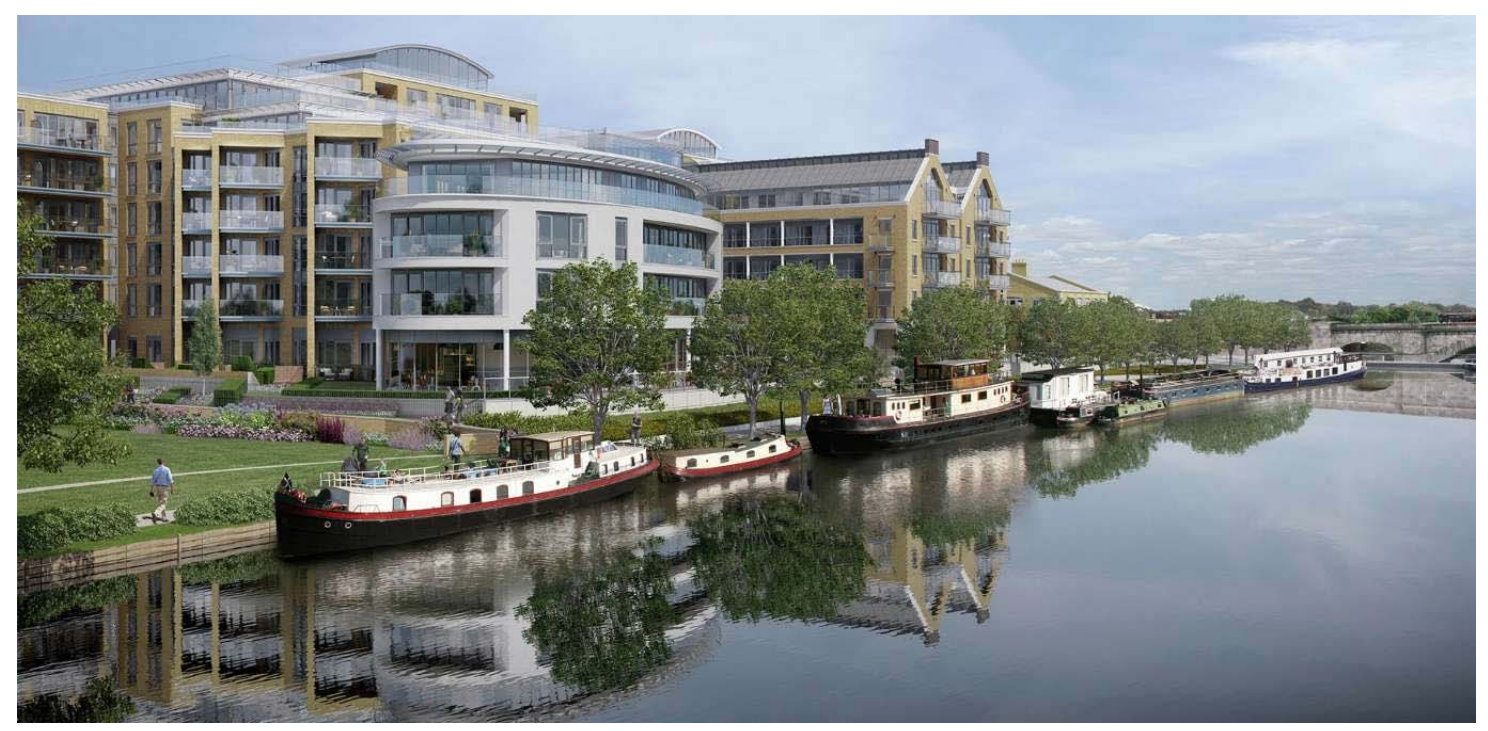

Fig. 1. Narrowboats moored next to Kew Bridge in London. Source: www.berkeleygroup.co.uk.

Hamburg is a forerunner in the area of housing on water in Germany. In 2006, city authorities issued a permit for the mooring of floating houses on local rivers and canals. Architects were given permission to design innovative solutions, without limitations in design or materials. One of the first water settlements, located in Eibekkanal, Hamburg and shown in Photograph 2, consists of ten units. The reason for the interest in floating houses is the desire to own a home near the center, high land prices, and the increasing population density in Hamburg (www.ndtv.com). Most of the houses are privately owned vessels. Although the purchase or construction of such units is more expensive than that of a traditional home, the lease of the bottom surface occupied by a vessel is much lower than the purchase or lease of land on shore at the same distance from the city center.

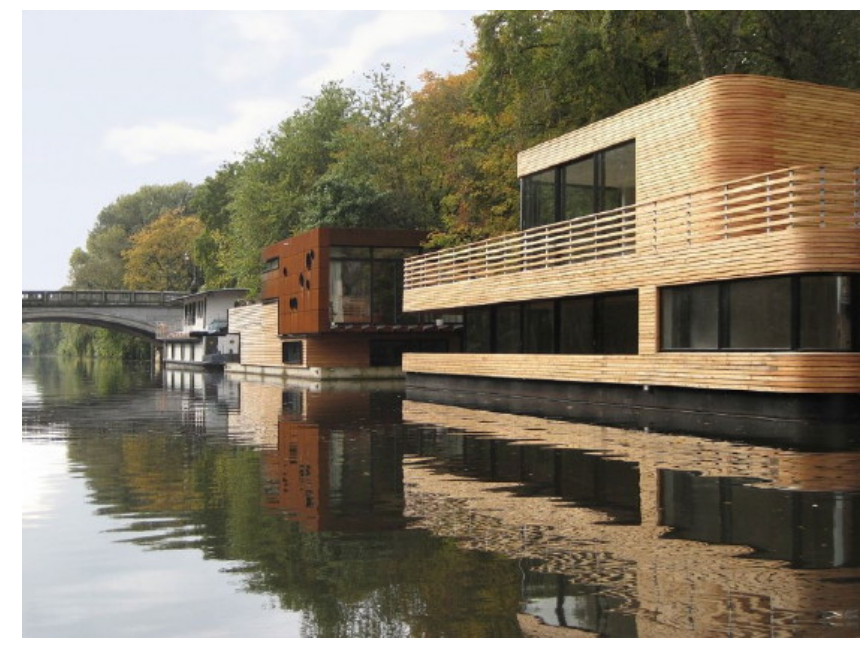

Phot. 2. Water homes in Eibekkanaal, Hamburg. Source: www.froot.nl.

Housing on water in North America, especially in the United States of America, has become a popular way of spending free time and is synonymous to the wealth of the society of the country. The identification of the inhabitants with their floating homes is so profound that it has prompted not only large areas of floating settlements to be created, but also an association which lobbies various tax and administration solutions. This is confirmed by government recognizing that "a floating home" is a 
legally permitted construction, which is not self-propelled and is subject to property tax. One of these associations is the Floating Homes Association - a civic group which represents the interests of the residents of more than 400 homes in five floating marinas on Richardson Bay; a map of these settlements has been shown in Figure 2. "Harbor housing" homes are privately owned, and the entire marinas operate as settlements located on land (floatinghomes.org).

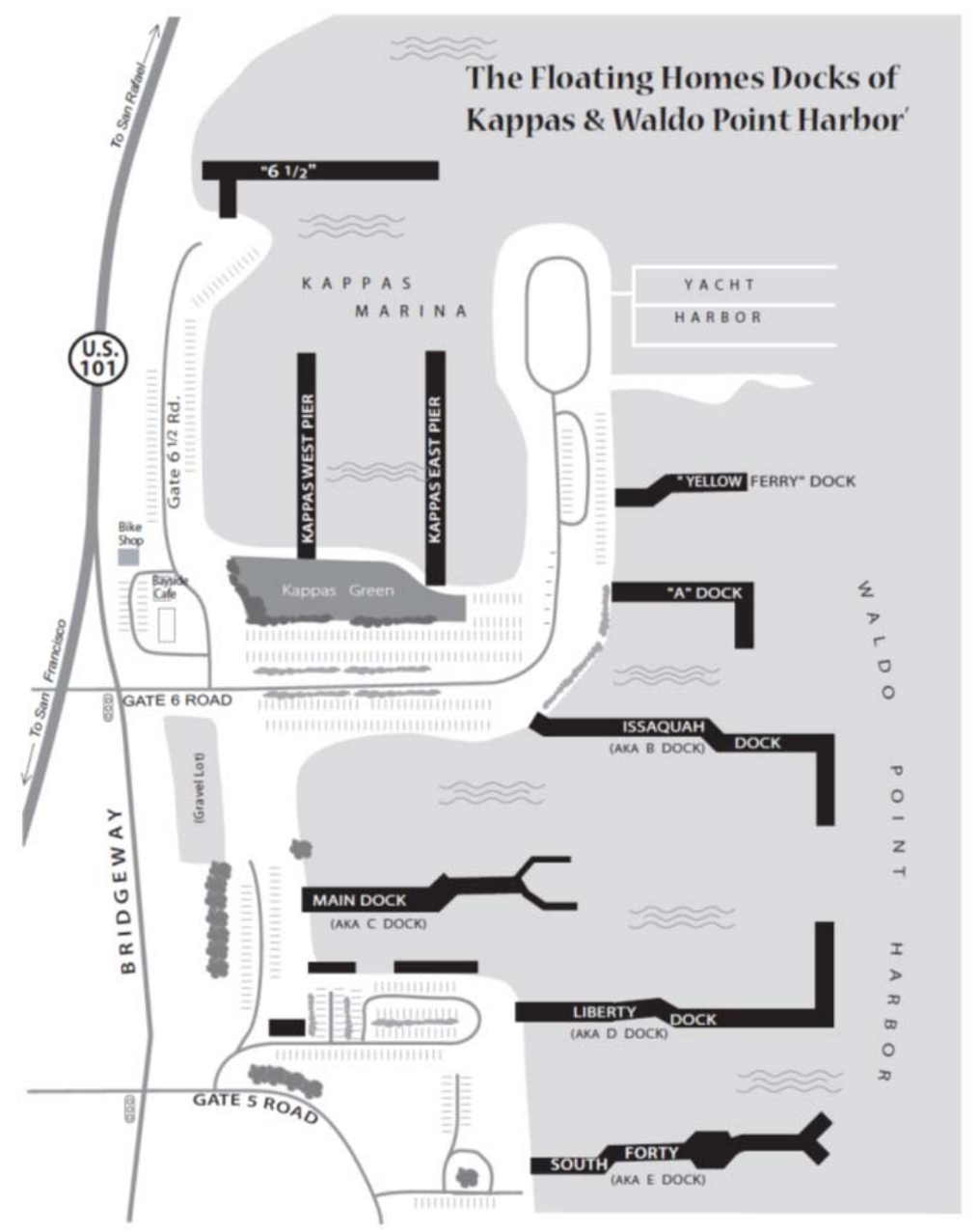

Fig. 2. A map of the floating settlement in Richardson Bay, USA. Source: Internet, www.froot.nl.

\section{Housing on water in Poland}

In Poland, conditions for the development of housing on water are not uniformly shaped; they undergo dynamic changes, and can currently be associated with:

- trends,

- the increasing level of wealth of the society,

- the necessity of developing post-industrial sites and former shipyards located by water,

- the density of housing in urban centers,

- the high cost of land and premises,

- the revitalization of waterfronts,

- environmental performance and closeness to nature,

- potentially lower maintenance costs,

- the modern nature of settlements on water.

The development of Polish cities in the last two decades has been taking place in a very expansive and dynamic manner. Developers and individual investors have been building up suburbs, ready settlements are being condensed, and suburban villages are becoming urban settlements. At the same time, this process is accompanied by the depopulation of the historic centers of cities. Historic Old Town areas are often cumbersome places to live in, due to intensive tourism and the entertainment character of these neighborhoods. A major problem is the degradation of downtown areas inhabited by poorer social strata struggling with social and economic problems. The revitalization process of 
these areas has been slow and, unfortunately, is all too often limited to merely the improvement of their aesthetics. The disadvantages of living in the city center often overshadow the benefits, which leads to the growing popularity of the suburbs. In the search for attractive investment areas in city centers, riparian areas are of exceptional potential (GOŁĘBIEWSKI 2013).

Wrocław is the pioneering city in construction on water in Poland. There are two houses with a surface area of $225 \mathrm{~m}^{2}$ and $65 \mathrm{~m}^{2}$ floating on its waters. The six-year-long investment process was tedious and long for the investor, as well as revealing a number of legal and competence problems. The complicated situation of a residential complex on water is multi-threaded and multi-faceted. The first and main problem is the lack of formalization of residential watercrafts in law. Another very important issue is the lack of regulation of matters concerning the ownership of land built-up with hydro-technical facilities. In Wroclaw, waterfronts were no longer owned by the municipal office, but have not yet been transferred to the possession of the Regional Water Management. This caused problems for the owner with obtaining a formal consent for berthing. In addition, the floating home owner was looking for a place for berthing by himself. This is wrong, because freely choosing a place for the vessel may cause a threat in the event of possible flooding, not only for the home but also for the bridges located along the canal or river. A competent agency with the jurisdiction to deal with aspects of flooding should designate areas safe for mooring. In the case of floating homes, it is hard to find areas of quays which will not only be safe, but also well-prepared to moor a floating home on a permanent basis. There are no adequate power connections, water and sewerage systems, land where waste can be stored, and assigned private parking space for a car.

Warsaw and Szczecin are examples of other Polish cities with an interest in the issue of floating houses. Czerniakowski Port, which used to be degraded, has become a convenient place to moor houses on water upon the dredging and refurbishment of quays. There are many advantages of this port, such as its location in close proximity to the center, excellent communication, providing a stable water level, and the avoidance of the river currents through a lock which separates the harbor from the Vistula riverbed. Szczecin, on the other hand, has made a step towards formal and legal solutions, as the city has adopted new local plans for riverside areas which provide a berth for floating homes.

\section{Management models of floating housing development in the world}

Observing models of the organization and functioning of areas occupied by residential floating houses mentioned in the second chapter, the author identifies four models of managing settlements on water. In order to understand the difference between these models, one should begin by pointing out the elements within residential complexes of floating homes and their function.

they A floating housing estate consists of:

- floating houses - residential facilities,

- floating piers - communication facilities,

- the waterfront - an element where water connects to the mainland (floating infrastructure with the land),

- hinterland - parking spaces, garbage containers, etc.,

- offices handling the estate - administrative function (this element is not optional).

In most cases, the management of floating housing development is a public and private partnership. This is due to the fact that, in most countries, water areas, e.g. canals, rivers and bays, are owned by cities or the state. In addition, most of these settlements are located on brownfield sites, or in former shipyards in city centers, in an agglomeration of closely-knit buildings. Changes in the function of the land, necessary in building plans, require a commitment on the part of local authorities. The driving force for their implementation is a private investor, who not only has a "vision", but also the capital necessary to finance a significant part of the investment.

Based on her observations, the author suggests the following division of management models of housing estates on water:

Model 1. Assumes the management of all the elements of the settlement on water, including the floating houses which have been prepared by an investor for rent or sale. In this model, the service office plays an additional role of a sales office and is situated on the estate.

Model 2. Anticipates the management of all elements of the estate with the exception of floating homes that are owned by private individuals. Residential watercrafts can be built from an individual, private project or purchased from a shipyard according to a standard project and delivered to the 
berth. The service office can be located on the estate or in another part of town, depending on the standard of "the marina" and charges.

Model 3. Based on the combination of Models 1 and 2 mentioned above. It is one of the most difficult solutions for the manager as well as the investor. This is due to the need to meet the requirements of permanent residents with the expectations of tourists. In this model, it is preferable that the office is on the estate.

Model 4. The public administration manages the area occupied by floating houses. In most cases, these activities are limited to charging the owners of the moored houses for the utilities and the land on the water bottom occupied by a floating house.

\section{Polish vision of the management model of floating housing developments}

In Poland, floating housing estates have not yet been built. This is due to the complexity of Polish laws, the absence of a legal definition of residential watercrafts, and the unclear ownership situation of hydro-technical facilities. One can identify some individual units moored to quays in Polish cities, but their location and functioning is not supported by any of the models of management presented above. In the current legal system, houses on water are treated as vessels. Therefore, based on these assumptions, one can attempt to outline a vision of how a "marina" of floating homes is to operate and be organized, based on combining experience from how harbors and residential areas operate.

In accordance with Article 10 point 1 of the Water Law, waters which are most suitable for locating housing estates of water homes are of public ownership, and remain the property of the State Treasury or its subdivision, as they are not tradable. Just as in the countries analyzed previously, the model of governance must be based on public and private partnership.

In the opinion of the author, Model 3 seems to be the most suitable as a vision of the functioning and organization of a floating housing estate in Poland, due to many assumptions presented later in the article.

Since most of the areas of former shipyards in Polish cities are located in the city center and remain the property of the city, it is the author's belief that they should remain as areas accessible to both residents and tourists. The administrator ought to organize a system of protecting the estate from damage and theft, as well as ensuring the safety of non-residents visiting the estate.

The approach to homeowners on water, as far as their needs are concerned, will be similar to that of residents of estates of detached houses. The main difference is evident in the issue of fee settlement, because the current legislation does not provide the possibility of signing contracts for the supply of utilities for homes on water. Therefore, the fees should be settled on the following basis:

- electricity - individual meter,

- water - individual meter,

- sewage - individual meter,

- parking spaces for cars - for example: flat rate per space.

The costs of administration, cleaning, ongoing maintenance, technical inspection, insurance, security and monitoring, and office maintenance should be included in the price of a mooring space on the basis of, e.g. the size of the floating object, location in the marina and downtime.

The management of waterside areas may prove difficult because of the need to balance the costs and revenues of the functioning of the settlements throughout the year. Due to the mobility of houses on water, the period of mooring can be divided into short-, medium-, long-term and permanent. Additionally, there is the question of seasonality, which is the division of the calendar year into a time of greater and lesser occupancy of spaces. Thus, the author proposes the following division of the season:

- high (May - September),

- low (October - April).

What is more, the diversity of the available technical solutions on the market, and the speed of their implementation, especially in terms of electrical wiring, water, wastewater and mooring systems necessitate a rapid response to the needs of homeowners.

Another aspect is the capacity of the marian, namely the layout of the mooring spaces. It should be organized to accept the maximum number of floating houses based on the size of the unit, time of its stay, and technical conditions permitted by the design and construction of the infrastructure. It is important to ensure that permanent and long-term residents feel comfortable, especially in the summer months when the interest in "marinas" is the greatest. 
Professional management of a floating housing estate will require the knowledge of legal acts in the field of property management, e.g. Construction Law, the Law on Real Estate, Law on Regional Planning, and Accounting Act. Moreover, the administrator should be well-acquainted with the regulations concerning water areas and navigation on the basin, as well as rules regarding the safety and operation of hydro-technical facilities, i.e. the Water Law, the Law on Inland Waterways and Maritime Areas of the Republic of Poland and Maritime Administration, and the Regulation on technical conditions to be met by hydro-technical structures and their location. Local legislation, provisions governing public and private partnerships, and legal acts relating to direct investors should also be mentioned.

The servicing staff of a floating housing estate, and especially its manager, should be familiar with the specificity and procedures in harbors, and sea and inland ports. Furthermore, it would be advisable for them to know the history of the place in which they have created the estate and have a fair knowledge of foreign languages (especially German and English) because short-term residents are going to visit the estate for tourist purposes. Therefore, the selection of staff working on a 24-hour basis will be very important, as they should be representative, meticulous and reliable. When the indicated management model is applied, it will require additional responsibilities, especially in the high season. These duties will involve:

- the rental of cars and bikes,

- the distribution of information materials about the country and the city,

- providing information on attractions in the city and the calendar of events,

- organizing guides,

- helping with the organization of basic services, i.e. laundry, ordering food, mail reception,

- assistance in mooring and repair of any damage to floating houses,

- ensuring access to the Internet.

The proper management of a floating housing development will be a complex process, requiring meticulous staff selection from the manager. These employees will assist the manager in striving to develop standards and operational systems of floating settlements in Poland.

\section{Management of hydro-technical facilities in Poland}

The creation of floating housing estates, apart from many problems of a legal and technical nature identified in the earlier part of the article, faces yet another difficult question regarding "the care" of the settlement and its inhabitants.

At the turn of 2013 and 2014, the Act of 13 June 2013 came into force. It amended the laws governing work in certain professions, according to which the number of requirements to be fulfilled by a candidate to obtain the right to perform the job was abolished. This deregulation has been extended to the profession of a real estate manager, but the duties and skills that such a person should possess remain unchanged (MISZEWSKA-URBAŃSKA, APOLLO 2014).

The deregulation of the profession of a real estate manager has resulted in opening the market to people who are unspecialized and unprepared for taking on this difficult profession. This means that the selection of individuals or companies involved in the management of floating housing developments in Poland will be more difficult and significantly postponed. As of today, we have still not established any settlement of watercrafts which could indicate a management model that could be analyzed not only in legal and functional terms, but also in the context of the professional skills of people dealing with this area of activity. This situation must change quickly considering that, since the Polish accession to the European Union, a need for the specialization of individuals and the emergence of firms in the field of the management of hydro-technical facilities has been observed.

Since the $1^{\text {st }}$ May 2004, Poland has been a full member of the European Union; therefore, it participated in the negotiations of the EU budget for 2007-2013. At that time, the country was allocated $€ 67.3$ billion from Structural Funds. The basic Polish document defining the priorities and system for delivering structural funds for the period 2007-2013 is the National Cohesion Strategy (National Strategic Reference Framework). The strategic objective of the National Cohesion Strategy is to create conditions for increasing the competitiveness of the Polish economy based on knowledge and entrepreneurship, as well as ensuring the growth of employment and an increase of the level of economic, social and spatial cohesion (www.agencjajj.pl). 
With the aid of European funds, the Pomerania Province completed two large projects related to the creation of hydro-technical infrastructure. The first one was coordinated by the Municipality of the City of Gdańsk and the Gdańsk History Museum, while the second one was piloted by the Pomerania Marshal's Office.

The Municipality of Gdańsk, with its partner - the Gdańsk History Museum, completed a project entitled: "The Revival of Waterways in Gdańsk" (PODWwG) under the Operational Program "Innovative Economy 2007-2013", Priority Axis 6. "Polish Economy on the International Market", Measure 6.4. "Investment in Tourism Products of Supra-Regional Importance". The value of the project totaled PLN 37,849,101.00, of which subsidies amounted to PLN 17,074,128.00, including the contribution of the European Union in the sum of PLN 14,513,008.80 (www.agencjajj.pl).

The aim of the project was to create regional products of supra-regional importance, including (www.gdansk.pl):

- the opportunity to explore the city of Gdańsk by waterway,

- rest and recreation for the whole family by water,

- maintaining security in the waterway and its surroundings.

As a result, a product was created, which was composed of two elements:

- infrastructure, i.e. 3 marinas and 10 water bus stops,

- two water bus lines with a total length of $45 \mathrm{~km}$.

Project: "Pętla Żuławska - Development of Water Tourism" was in the first entry on the indicative list of individual projects in the Operational Program- Innovative Economy 2007-2013, Measure 6.4. "Investments in Tourism Products of Supra-Regional Importance". The aim of the project is tourism, cultural and economic development, the enhancement of urban areas, and increasing public safety. A tourism product was developed, which consists of an original composition of tourism products and services that can be used during the stay in Żuławy and the Vistula Lagoon. The project has been piloted since 2005 by the Marshal of the Pomerania Province. The partners in the project are: The Regional Water Management, The Office of the Marshal of the Warmia and Mazury Province and the municipalities of both provinces (including the City of Gdansk) located on the Vistula Delta. The project covered the water area of the Vistula River, the Dead Vistula, Szkarpawa, the Królewiecka Vistula, the Nogat, the Jagiellonian Channel, and others. The total project value is PLN 83,508,508.18, and the amount of assistance from grants is PLN 49,071,615.00 (www.pot.gov.pl).

The feasibility study for both projects assumed that during the shelf life, the infrastructure would be managed by an external company, a so-called "Operator". The operator should be selected through a procedure laid down in the feasibility study, in accordance with procedures provided for in the Public Procurement Law. Some of the duties of the administrator would include charging fees, the employment of staff, cleaning the object, and carrying out technical inspections and repairs.

Unfortunately, multiple attempts to choose the operator for the infrastructure recovery program of waterways in Gdańsk have failed. In the case of Pętla Żuławska, only four out of nine facilities were taken over by managing companies to operate from March to September. Entrepreneurs representing the trade industry, water tourism enthusiasts and utility companies all took part in the proceedings. This is particularly worrying in view of the fact, that a large part of the EU grant is intended for the development of tourism, including water tourism. If there is a problem with finding a competent company or individual to manage marinas that have existed in Poland for years, it will be even more difficult to find a manager who undertakes the responsibility of "looking after" a floating housing estate and pursue the appropriate management model.

The importance of issues related to the management of hydro-technical facilities, i.e. waterfront, marinas or harbors, is the subject of many publications throughout the world, including VERHOEVEN P., VANOUTRIVE T., 2012 A quantitative analysis of European governance port. and GORDON D., 1997, Managing the Changing Political Environment in Urban Waterfront Redevelopment, as well as in Poland MISZEWSKA-URBAŃSKA E., WIŚNIEWSKI R., 2013 Management plan as an essential tool in making decisions related to the preparation of the investment process of hydraulic structures for water.

This problem is seen and noticed both at state and local government institutions, because, as the main beneficiaries of EU funds, they have difficulties with maintaining subsidies, as well as the operation and organization of work connected with hydro-technical facilities built with funds from EU grants. One of the recent solutions to the lack of specialized companies on the management market is a change in the structures of public administration institutions, especially those related to sports and recreation. Their operation is based largely on the administration rather than the management of 
objects. The degree of technical knowledge is not satisfactory, and the organizational structure turns decision-making into a multi-leveled process, and thus extended in time and subject to regulations. Therefore, a solution to the problem is a public partnership based on the experience of countries such as Germany, the Netherlands and the United States of America, which should be a driving force for changes in the law and awareness of legislators in Poland.

\section{Summary}

On the basis of the observation of trends in European and North American countries, one can differentiate four main models of the management of floating housing developments. The differences between the models of management are largely due to various factors that determine the development of floating housing construction and the different legal requirements in force in each country. The common organizational and functional element is a public and private partnership.

In Poland, one can come across some individual moorages for floating houses, but the rise in floating housing estates seems to be a concept for the distant future. The reason is the failure to indicate the key factor for the development of floating homes along with a wide spectrum of formal, legal and technical problems.

The main perceptible and noticeable problem at the moment is the lack of specialized individuals or companies ready to meet the challenges of the modern-day management of hydro-technical facilities, including floating housing developments. Changing this situation is very important as new hydro-technical facilities which must be managed by someone have come into existence. This is not a simple operation due to the conditions resulting from the nature of hydro-technical facilities and the provisions of grant agreements with the European Union. Without specialists in the management of hydro-technical facilities, the development of floating housing estates in Poland will be very slow and the identification of an appropriate management model will be hindered.

\section{References}

BAŃKOWSKA B., 2000, Ogólne zasady kształtowania frontów wodnych w miastach, (General Principles of Forming Fronts of Water in Cities) [in:] Sieć miast Bałtyckich - Waterfront. Elbląska strefa nadwodna jako produkt turystyczny. Potencjalne możliwości rozwoju turystyki w regionie Zalewu Wiślanego oraz w porcie elbląskim - uwarunkowania akwenów i stref lądowych, (Copyright papers presented at the seminar on $20^{\text {th }}$ April 2000 (unpublished) ECOBALTIC Foundation, Institute for Sustainable Development, Gdańsk).

GERIGK M., 2013, Wykorzystanie obszarów morskich pod zabudowe o przeznaczeniu wielofunkcyjnym, (Exploitation of Water Resources for Multifunctional Building), Zeszyt Naukowy 82/2013, (Faculty of Navigation, the original version of the journal is an electronic version. Security issues in maritime transport, scientific editor of the edition, PhD. Eng. Capt. Adam Weintrit, prof. Associate. Maritime Academy in Gdynia).

Gordon D., 1997, Managing the Changing Political Environment in Urban Waterfront Redevelopment, Urban Studies, Vol.34, No.1, pp. 61-83.

HARMS H., 1997, Changes on the Waterfront - Transforming Harbor Areas. Comparison and Evaluation of Waterfront Developments in Two Contexts: San Francisco Bay Area and Hamburg, Germany. Preliminary Presentation at Shrinking Cities Conference, February 2007, University of California, Berkeley (reorganized October 2007).

Hoyle B., 2000, Global and Local Change on the Port City Waterfront, Geographical Review, Vol.90, No.3, pp. 395-417.

Internet sources: www.agencjajj.pl (28.01.2014);

Internet sources: www.pot.gov.pl (20.01.2014);

Internet sources: www.gdansk.pl (27.01.2014);

Internet sources: www.amusingplanet.com (28.09.2015);

Internet sources: www.berkeleygroup.co.uk_(28.09.2015);

Internet sources: www.ndtv.com (29.09.2015);

Internet sources: www.froot.nl (29.09.2015);

Internet sources www.floatinghomes.org) (29.09.2015)

KOCHANOWKI M. (red.), 1998, Wspótczesne metamorfozy miast portowych, (Today's Metamorphosis of Port Cities), Gdańsk University of Technology, Gdańsk. 
LORENS P., 2004, Rewitalizacja frontów wodnych jako element procesu odnowy miast, (Revitalisation of Waterfronts as a Part of the Urban Renewal Process), [in:], Przestrzen w zarządzaniu rozwojem regionalnym lokalnym, K. Markowski (red.), Bulletin of KPZK PAN (Polish Academy of Sciences), Issue 211, PG. pp. 179-205.

MiSZEWSKA-URBAŃSKA E., 2014, Rola nowego tramwaju wodnego w Gdańsku, (Function of a New Water Bus in Gdańsk ) Logistyka - No. 3 (2014), pp. 4438-4446.

MisZEWSKA-URBAŃSKA E., APOLlO M., 2014, System Informacji Przestrzennej jako narzędzie wspierajacej wykonywanie obowiązków związanych zarządzaniem nieruchomościa, (Spatial Information System as a Tool to Perform Duties Related to Property Management), Logistyka No. 6/2014, pp. 12012-12021.

MiSZEWSKA-URBAŃSKA E., WIŚNIEWSKI R., 2013, Plan zarządzania jako narzędzie niezbędne w podejmowaniu decyzji związanych z przygotowaniem procesu inwestycyjnego dla wodnych budowli hydrotechnicznych, (Management Plan as an Essential Tool in Making Decision Related to the Preparation of the Investment Process for Water Hydrotechnical Structures), Inżynieria Morska i Geotechnika (Maritime Engineering and Soil Technology) - No. 5 (2013), pp. 412-415.

MUSZYŃSKA - JELESZYŃSKA D., 2013, Tereny nadrzeczne w aspekcie rozwoju i rewitalizacji miast. (Riverside Areas in Terms of Development and Urban Regeneration). Journal of Health Sciences. 2013; 3(14), 99107.

PANCEWICZ A., 2004, Rzeka w krajobrazie miasta, (River in the City Landscape), (Silesian University of Technology, Gliwice.

Ustawa Prawo budowlane z dnia 7 lipca 1994 r. (Dz. U. 1994 Nr 89 poz. 414, opracowano na podstawie: t.j. Dz. U. z 2013 r. poz. 1409, z 2014 r. poz. 40, 768, 822, 1133, 1200), (Act Building Code of 7 July 1994 (Journal of Laws 1994, No. 89 item 414, prepared on the basis of Journal of Laws 2013 item 1409 of 2014 items 40, 768, 822, 1133, 1200)).

Ustawa Prawo zamówień publicznych z dnia 29 stycznia 2004 r. (Dz. U. 2004 Nr 19 poz. 177, opracowane na podstawie: Dz. U. z 2013 r. poz. 907, 984, 1047, 1473, z 2014 r. poz. 423, 768, 811, 915, 1146, 1232), (Act Public Procurement Law of 29 January 2004, (Journal of Laws 2004 No. 19 item 177, prepared on the basis of Journal of Laws of 2013 items 907, 984, 1047, 1473, of 2014, items 423, 768, 811, 915, $1146,1232))$.

Ustawa Prawo wodne z dnia 18 lipca 2001 r.,(Dz. U. 2001 nr 115 poz. 1229, opracowane na podstawie: Dz.U. z 2015 r. poz. 469), (Act Water Law of 18 July 2001, (Journal of Laws 2001 No. 115 item 1229, prepared on the basis of Journal of Laws 2015 item 469)).

Ustawa o zmianie ustaw regulujących wykonywanie niektórych zawodów z dnia 13 czerwca 2013 r (Dz. U. z 2013 r. poz. 829), (Act amending the laws governing the practice of certain professions of 13 June 2013 (Journal of Laws of 2013 item 829),

Verhoeven P., VAnOUTRIVE T., 2012, A Quantitative Analysis of European Port Governance. Maritime Economics \& Logistics (2012) 14, pp. 178-203. 